\title{
A specific fluorescence probe for hypochlorous acid based on rhodamin101 thiosemicarbazides and its application for living cells imaging
}

\author{
Bo-Song Zhu ${ }^{1}$, Zhi-Xiang Han ${ }^{1,}$, Tong-Liang $\mathrm{Wu}^{1}$, and Xiang-Yang $\mathrm{Wu}^{1}$ \\ ${ }^{1}$ School of the Environment and Safety Engineering, Jiangsu University, Zhenjiang, 212013, P. R. \\ China \\ azhixianghan69@126.com
}

Keywords: Rhodamine 101; Hypochlorous Acid; Bioimaging; Living cells

Abstract. Utilizing the mechanism of HOCl-mediated cyclization of rhodamine 101 thiosemicarbazide (non-fluorescent) to rhodamine 101 oxadiazoles (fluorescent), we successfully developed a novel off-on far-red fluorescent probe (1) toward $\mathrm{HOCl}$ with high selectivity, great functionality at physiological $\mathrm{pH}$ and good cell-membrane permeability. Probe $\mathbf{1}$ was linearly proportional to the concentration of $\mathrm{HOCl}$ in the range of $1-10 \mathrm{M}$ and the detection limit is $0.3 \mathrm{M}$. Moreover, the proposed probe (1) was successfully used for the detection of hypochlorous acid in HepG2 cells by fluorescent imaging.

\section{Introduction}

Owing to the variety functions in biological processes, reactive oxygen species (ROS) have received more and more considerable attention of chemist and biologist in recent years ${ }^{[1]}$. Hypochlorous acid ( $\mathrm{HOCl})$ is a biologically significant ROS that exists in equilibrium with hypochlorite $\left(\mathrm{OCl}^{-}\right)$at physiological $\mathrm{pH}$. Normal level $\mathrm{HOCl}$ is a critical microbicidal agent in natural defense ${ }^{[2]}$. Abnormal levels of $\mathrm{HOCl}$ would lead to many inflammation-related diseases ${ }^{[3]}$, including cardiovascular diseases, damage of human red blood cells, lung injury, rheumatoid arthritis, and cancer. Thus, develop the detection of $\mathrm{HOCl}$ is of great importance.

In comparison with trantional methods, fluorescence method is well known for its high sensitivity, high selectivity, simple manipulation and lack of a requirement for sophisticated instrumention $^{[4]}$. In addition, in conjunction with microscopy, bio-imaging applications can be used in living cells. Based on the reported $\mathrm{ClO}^{-}$probes ${ }^{[5-9]}$, they have the drawbacks like unsuitable $\mathrm{pH}$ range for cells ${ }^{[7,9]}$, lack of selectivity between $\mathrm{ClO}^{-}$and $\mathrm{Cu}^{2+}$ or $^{\mathrm{H}_{2} \mathrm{O}_{2}}{ }^{[8]}$ or $\mathrm{UV}$ excitation ${ }^{[9]}$. Therefore, it has profound meanings to develop one bioimaging probe for $\mathrm{HOCl}$ with an excellent selectivity and sensitivity that is applicable to various biological systems.

Due to the spirolactam structural property, rhodamine derivate framework is an ideal model to construct "turn-on" fluorescent chemosensors ${ }^{[10]}$. However, rhodamine B or 6G is the main fluorophore to construct off-on probe for various metal ions, anions or ROS and so on. Obvisously, the development of rhodamine analogues with longer absorption and emission in far-red or near infraed region still presenrt ample opportunities and will be more suitable for biological application. Rhodmaine 101 has two amino groups rigidly linked to the xanthene skeleton at 3 and 6-position by multiple n-propylene bridges which elongate its emission to far-red region (>600 $\mathrm{nm}$ ).

Inspired by Lin's work ${ }^{[1]}$, in this paper, we described a novel $\mathrm{HOCl}$-amplified fluorescent probe based on $\mathrm{HOCl}$-promoted cyclization of rhodamine 101 thiosemicarbazide to rhodamine 101 oxadiazoles reaction mechanism with high selectivity and its application in cell imaging. 


\section{Experimental}

Reagents and apparatus. Before used, N, N-dimethylformamide (DMF) was freshly distilled after dried by anhydrous $\mathrm{MgSO}_{4}$ for $24 \mathrm{~h}$. All other reagents used were of analytical reagent grade. Twice distilled water was used throughout all experiments.

${ }^{1} \mathrm{H}$ NMR and ${ }^{13} \mathrm{C}$ NMR spectra were recorded on a Bruker Avance II 400 spectrometer and LC-MS analysis was performed using an LXQ Spectrometer (Thermo Scientific, USA). UV-vis absorption spectra were recorded on a Shimadzu UV-2600 spectrophotometer. All fluorescence measurements were conducted on a Thermo Scientific Lumina fluorescence spectrometer with excitation slit set at $5.0 \mathrm{~nm}$ and emission at $5.0 \mathrm{~nm}$. Fluorescence images of HepG2 cells were carried out with an inverted fluorescence microscope (Carl Zeiss, Axio ObserverA1).<smiles>NN1C(=O)c2ccccc2C12CCCN1CCCc3c(cc4c(c31)OCCN1CCCCC41)C2</smiles>

2

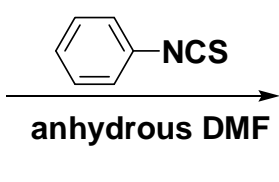

Scheme 1. Chemical structure and synthetic route of compound $\mathbf{1 .}$

Synthesis of compound 1. Synthetic routes of probe 1 are depicted in Scheme 1, and it was fully characterized by ${ }^{1} \mathrm{H}$ NMR, ${ }^{13} \mathrm{C}$ NMR, and mass spectrum. Briefly, Phenyl isothiocyante (20 mg, 0.15 mmol) was added to the solution of rhodamine 101 hydrazide $^{[12]}(50.4 \mathrm{mg}, 0.1 \mathrm{mmol})$ in DMF $(2 \mathrm{~mL})$ in potions and then heated to $50{ }^{\circ} \mathrm{C}$ with stirring. After $12 \mathrm{~h}$, the mixture was cooled and the solvent was removed under reduced pressure, then the residue was purified on silica gel chromatography eluted with $\mathrm{CH}_{2} \mathrm{Cl}_{2} / \mathrm{EtOAc}(3: 1, \mathrm{v} / \mathrm{v})$ to afford the desired product as a light purple solid (49 $\mathrm{mg}$, yield $76.7 \%)$.

${ }^{1} \mathrm{H}$ NMR $\left(400 \mathrm{MHz}, \mathrm{CDCl}_{3}\right): \delta 1.77-1.88(\mathrm{~m}, 8 \mathrm{H}), 2.41-2.47(\mathrm{~m}, 4 \mathrm{H}), 2.84-3.01(\mathrm{~m}, 4 \mathrm{H})$, 3.08-3.13 (m, 4H), 3.17(t, J = 5.6Hz, 4H), $6.03(\mathrm{~s}, 2 \mathrm{H}), 6.99(\mathrm{~s}, 1 \mathrm{H}), 7.10(\mathrm{~d}, \mathrm{~J}=7.6 \mathrm{~Hz}, 2 \mathrm{H}), 7.16(\mathrm{~d}$, $\mathrm{J}=7.2 \mathrm{~Hz}, 1 \mathrm{H}), 7.24(\mathrm{~s}, 1 \mathrm{H}), 7.28(\mathrm{~d}, \mathrm{~J}=3.2 \mathrm{~Hz}, 2 \mathrm{H}), 7.57-7.61(\mathrm{~m}, 2 \mathrm{H}), 7.63-7.67(\mathrm{~m}, 1 \mathrm{H}), 8.02(\mathrm{~d}, \mathrm{~J}$ $=7.2 \mathrm{~Hz}, 1 \mathrm{H}) .{ }^{13} \mathrm{C}$ NMR $\left(100 \mathrm{MHz}, \mathrm{CDCl}_{3}\right): \delta 21.137,21.238,21.724,27.286,49.402,49.799$, 68.001, 104.068, 108.339, 117.892, 123.308, 123.709, 124.898, 124.973, 126.005, 128.322, 128.875, 134.257, 137.765, 144.330, 149.157, 150.753, 167.358, 182.661. MS: $[\mathrm{M}+\mathrm{H}]^{+}=640.23$, calculated: $[\mathrm{M}+\mathrm{H}]^{+}=640.27$.

\section{Results and discussion}

a)

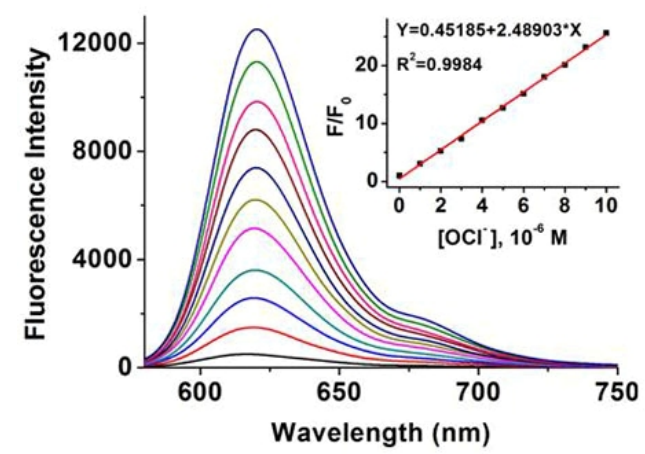

b)

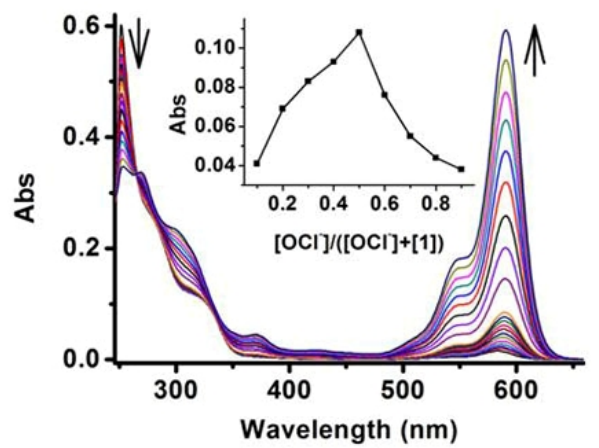

Fig.1 Changes in fluorescence emission $\left(\mathrm{a}, \lambda_{\mathrm{ex}}=550 \mathrm{~nm}\right)$ and absorption $(\mathrm{b})$ spectra of $1(10 \mu \mathrm{M})$ upon addition of increasing concentrations $\left(0 \sim 10 \mu \mathrm{M}\right.$, from bottom to top ) of $\mathrm{NaOCl}$ in test system. Inset (a): The plot of $F / F_{0}$ as a function of the concentration of $\mathrm{NaOCl}$. Inset (b): Job's plots for $\mathbf{1}$ in test syetem ( the total concentration of $\mathbf{1}$ and $\mathrm{NaOCl}$ was $20 \mu \mathrm{M})$. 
Spectral Characteristics. The fluorescence titration of $\mathrm{NaOCl}$ was perform with a solution of $10 \mu \mathrm{M}$ of probe 1 in test system ( $\mathrm{pH}=7.40 \mathrm{~PB} / \mathrm{DMF}, 1: 1, \mathrm{v} / \mathrm{v}$ ). As shown in Fig. 1a, the probe 1 displayed almost no considerable emission bands above $600 \mathrm{~nm}$, indicating that it exists as the ring-closed form. With increasing concentration treatment of $\mathrm{NaOCl}$ with probe $\mathbf{1}$, a strong visible emission band centered at $620 \mathrm{~nm}$ with 25-fold fluorescence enhancement (treated by $10 \mathrm{M} \mathrm{NaOCl}$ ) was observed, suggesting that $\mathrm{NaClO}$ promotes the transformation of probe $\mathbf{1}$ from the ring-closed form to the ring-opened form. Meanwhile, a slight red shift from $617 \mathrm{~nm}$ to $620 \mathrm{~nm}$ also can be observed at the maximum emission. The fluorescent response of probe 1 towards $\mathrm{NaOCl}$ was calculated to cover a linear range from 1 to $10 \mathrm{M}$ (Fig. 1a, inset), with a detection limit of $0.3 \quad \mathrm{M}$ (based on $\mathrm{S} / \mathrm{N}=3$ ). Figure $1 \mathrm{~b}$ showed the variation of probe $\mathbf{1}$ on the gradual addition of $\mathrm{NaClO}$ in test system. The colorless probe 1 shows almost no absorption in visible region. Upon the gradual addition of $\mathrm{NaClO}$ to the solution of probe 1, a new absorption peak at $585 \mathrm{~nm}$ emerged with increasing intensity. The solution displayed a clear change from colorless to pink simultaneously, implying that the conversion from spirolactam to the ring-opened amide occurred. Moreover, the absorbance enhanced accompanied with the increase of $\mathrm{NaOCl}$ concentration. Job's method for the absorbance was applied to determine the stoichiometry of the $1-\mathrm{NaOCl}$ complex by keeping the total concentration of $\mathrm{NaOCl}$ and 1 at $20 \quad \mathrm{M}$ and continuously changing the molar ratio of $\mathrm{NaOCl}$ from 0 to 1 . As shown in Fig. $1 \mathrm{~b}$ inset, a maximum absorption was observed when the molar fraction of $[\mathrm{NaOCl}]$ vs. $([\mathbf{1}]+[\mathrm{NaOCl}])$ was 0.5 , which strongly indicated that a 1:1 adduct was formed with $\mathbf{1}$.

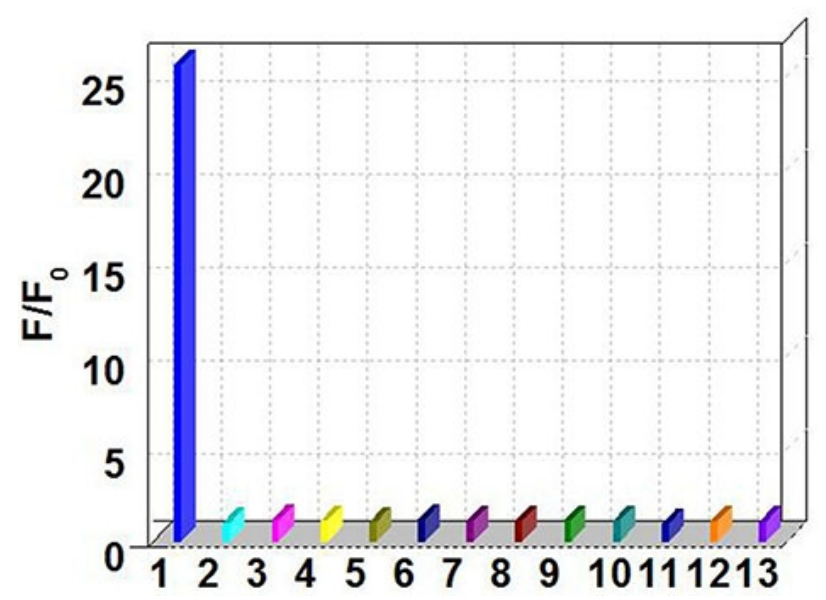

Fig.2. Fluorescence response of $\mathbf{1}(10 \mu \mathrm{M})$ to $10 \mu \mathrm{M}$ of selected analytes in test system. Bars represent the emission insensity ratios after $(\mathrm{F})$ and before $\left(\mathrm{F}_{0}\right)$ addition of each analyte. (1) $\mathrm{NaOCl}$; (2) blank; (3) $\mathrm{Br}^{-} ;(4) \mathrm{SO}_{4}{ }^{2-} ;(5) \mathrm{ClO}_{4}^{-}$; (6) $\mathrm{Cl}^{-}$; (7) $\mathrm{F}^{-}$; (8) $\mathrm{NO}_{3}^{-}$; (9) $\mathrm{PO}_{4}{ }^{3-}$; (10) $\mathrm{I}^{-}$; (11) $\mathrm{CO}_{3}{ }^{2-}$; (12) $\mathrm{OAc}^{-}$; (13) $\mathrm{H}_{2} \mathrm{O}_{2}$. Excitation wavelength was $550 \mathrm{~nm}$.

Selectivity. Selectivity is an important aspect to evaluate the performance of probe 1. As shown in Fig. 2, probe $\mathbf{1}$ displayed a remarkable selectivity only for $\mathrm{HOCl}$ over others biologically relevant species representted by $\mathrm{F}^{-}, \mathrm{Cl}^{-}, \mathrm{Br}^{-}, \mathrm{I}^{-}, \mathrm{CH}_{3} \mathrm{COOOH}, \mathrm{NO}_{2}^{-}, \mathrm{ClO}_{4}{ }^{-}, \mathrm{NO}_{3}{ }^{-}, \mathrm{CO}_{3}{ }^{2-}$, $\mathrm{SO}_{4}{ }^{2-}, \mathrm{HCO}_{3}{ }^{-}, \mathrm{H}_{2} \mathrm{O}_{2}$.

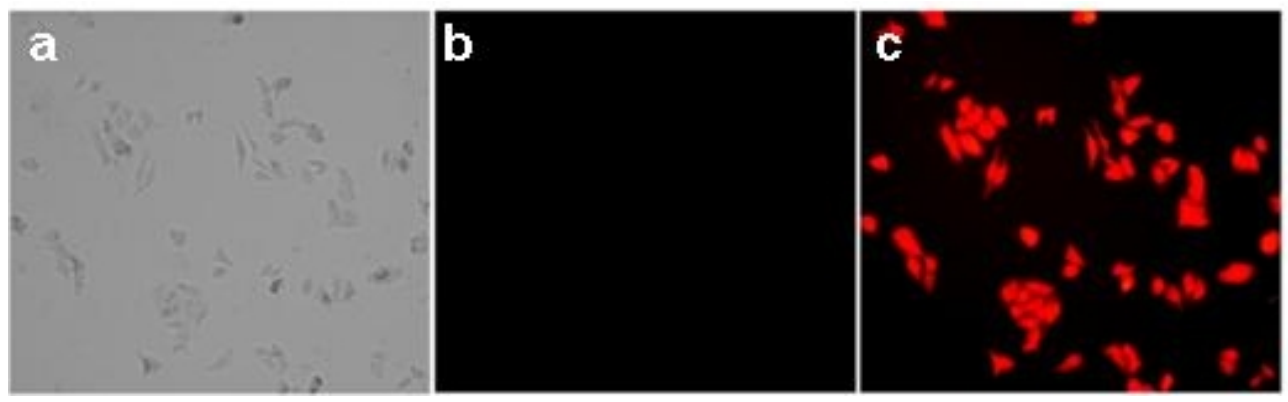

Fig. 3. Bright-field transmission image (a) and fluorescence image (b) of HepG2 cells incubated with $\mathbf{1}(10 \mu \mathrm{M})$ for 30 min. (c) Fluorescence image of the cells above further incubated with $10 \mu \mathrm{M} \mathrm{NaOCl}$ for another $30 \mathrm{~min}$. 
Detection of $\mathbf{N a O C l}$ in living cells. To explore the potentical practical applications, probe $\mathbf{1}$ was employed for in vitro $\mathrm{HOCl}$ detection in living cells on an inverted fluorescence microscope. In the abscence of $\mathrm{NaOCl}$, no significant fluorescence could be observed (Fig. 3b). After incubation with $\mathrm{HOCl}$, however, a bright fluorescence was observed in living cells (Fig. 3c). These results reveal that probe 1 was well permeable to efficiently image intracellular hypochlorous acid under fluorescence microscope.

\section{Conclusions}

Rhodamine 101 - thiomicarbazides has been developed as a novel fluorescent probe for $\mathrm{HOCl}$. Its excellent characteristics, including high selectivity, working at physiological $\mathrm{pH}$, emission in far-red region, enable us to measure $\mathrm{HOCl}$ in living cells by fluorescence technique with successful results.

\section{Acknowledgements}

This work was financially supported by the National Natural Science Foundation of China (21105038), the Opening Project of State Key Laboratory of Chemo/Biosensing and Chemometrics of Hunan University (2010007, 2014015), China Postdoctoral Science Foundation (2013M541604), Jiangsu Postdoctoral Science Foundation (1301047B), the Scientific Research Foundation for the Talents in Jiangsu University (10JDG035) and collaborative innovation center of water treatment technology \& material of Jiangsu province.

\section{References}

[1] J.D. Lambeth. Free Radic Biol Med. Vol. 43 (2007), p. 332.

[2] J.M. Albrich, C.A. McCarthy, and J.K. Hurst. Proc. Natl. Acad. Sci. U. S. A. Vol. 78 (1981), p. 210.

[3] B.C. Dickinson, and C.J. Chang. Nat. Chem. Bio., Vol. 7 (2011), p. 504, and references therein.

[4] A.P. Demchenko, Introduction to Fluorescence Sensing, Springer, 2008;

[5] X.Q. Chen, X.Z. Tian, I. Shin et al. Chem. Soc. Rev., Vol. 40 (2011), p. 4783.

[6] L. Yuan, L. Wang, B.K. Agrawalla, et al. J. Am. Chem. Soc. Vol. 137 (2015), p. 5930.

[7] X.Q. Chen, X.C. Wang, S.J. Wang, et al. Chem. Eur. J. Vol. 14 (2008), p. 4719.

[8] Y.L. Liu, Y. Sun, J. Du, et al. Org. Biomol. Chem. Vol. 9(2011), p. 432.

[9] W.Y. Lin, L.L. Long, B.B. Chen, et al. Chem. Eur. J. Vol. 15 (2009), p. 2305.

[10] X.Q. Chen, T. Pradhan, F. Wang et al. Chem. Rev. Vol. 112(2012), p. 1910, and references therein.

[11] L. Yuan, W.Y. Lin, Y.N. Xie, et al. Chem. Eur. J. Vol. 18(2012), p. 2700.

[12] P.H. Xie, F.Q. Guo, D. Li, et al. J. Lumin. Vol. 131 (2011), p. 104. 